\title{
Revaluing paste and thickened tailings for large tonnage applications
}

AJ Vietti Vietti Slurrytec (Pty) Ltd, South Africa

\begin{abstract}
A decade ago, paste and thickened tailings (P\&TT) disposal was regarded as a potential technology for eliminating so-called wet tailings dams. Despite numerous very successful examples of both surface and backfill applications, by 2015, confidence in the technology had waned after the technical difficulties encountered at two high-profile, large tonnage copper tailings projects in South America. The recent spate of deadly tailings dam disasters has refocused public and private sector attention on conventional tailings disposal. The knee-jerk reaction from the mining industry has been to ignore P\&TT and focus on dry stacking as the solution to the problem, which itself is still a relatively immature technology for large tonnages.

This paper attempts to explain the apparent lack of recognition that P\&TT as a legitimate and safe tailings disposal method has received. A chronological review of P\&TT technology implementation and possible reasons for its loss of favour, particularly in large tonnage applications, is provided.
\end{abstract}

Keywords: dewatering, filtration, tailings, thickening

\section{$1 \quad$ Introduction}

In the aftermath of the catastrophic 2019 Corrego de Feijão tailings dam failure in Brumaldinho, Brazil, the Investors Mining and Tailings Safety Initiative was set up to conduct the 'Global Tailings Review', the output of which was to establish a global tailings standard under an independent chair and expert panel. A tailings disclosure document was issued to 726 publicly listed mining companies and detailed information regarding the location, age, construction method, etc. of tailings storage facility (TSF) sites was collected and electronically published in the Global Tailings Portal (www.tailing.grida.no), and more recently in a paper summarising the stability risks of various TSF construction methods (Franks et al. 2021). Although several construction methods are defined in the portal and the paper, they appear to cover only two tailings dewatered states:

- Tailings dewatered by conventional or high-rate thickeners to a 'thickened' state in which upstream, downstream, centreline and hybrid TSF construction methods are used.

- Tailings dewatered by filtration to a 'dry' state suitable for dry stacking TSF construction methods.

In-pit disposal is also defined, but surprisingly, construction methods using non-segregating tailings, i.e. paste and thickened tailings (P\&TT) disposal, are not considered.

Why has there been this apparent lack of recognition of P\&TT as a legitimate and safe disposal tailings methodology at this highest level of tailings governance even though there are hundreds of successfully operated P\&TT backfill and surface tailings operations globally?

To answer this question, the author provides three possible underlying reasons for this apparent lack of awareness based on personal experience in the field covering the last 30 years. Of the three reasons offered, two relate to a general lack of clarity within the tailing fraternity and the mining community, and a third relates to the developmental hurdles and a loss of confidence in a maturing technology. 


\section{Defining P\&TT schemes according to the tailings dewatered state}

The global tailings fraternity consists of a very small group of international consultants, personnel from mining companies, and original equipment manufacturers (OEMs). Within this group, but especially at the level of decision-makers within the mining companies, there appears to be a lack of clarity of what paste or high-density tailings disposal is. This is illustrated by a cursory review of the major mining company web pages describing what tailings are and how they are disposed. In almost all cases, tailings disposal is equated to conventional TSF construction methods using segregating tailings. Only one company recognises that tailings can be categorised in terms of their degree of dewatering from thickened tailings (segregating slurry) to paste (non-segregating slurry) and finally dry stack (filter cake).

Dewatering of tailings for surface disposal falls within the metallurgical discipline at a typical mineral processing plant, and the degree of dewatering depends on the type of dewatering technology used together with the tailings slurry physical and chemical properties. Although it must be said that given sufficient time, any type of thickener may be able to generate a high-density, non-segregating underflow, in general, conventional and high-rate thickeners (HRT) under normal operating conditions are not designed to or capable of generating high-density underflow on a continuous basis. In most cases, the tailings are dewatered to a low density, low yield stress, and segregating consistency before disposal. Tailings of this nature are suitable for conventional TSF construction methods only, i.e. upstream; downstream and centreline.

In contrast, so-called 'paste' thickeners that incorporate pickets onto the rotating rake mechanisms and are supplied with high rake torque capability can dewater tailings to a high-density state that has both high yield stress and is non-segregating. Tailings in this state are suitable for disposal by P\&TT construction methods, i.e. central thickened discharge (CTD) and down valley discharge (DVD). From a technical perspective, the rotating pickets within these thickeners provide shortened paths for trapped interstitial water to escape from the consolidating mud bed. Therefore, the processes of sedimentation and densification are accelerated within the available thickener mud bed residence time of typically three to five hours (Figure 1). Paste thickeners represent the top end of the slurry dewatering scale by gravity sedimentation methods. Further dewatering to a 'dry' state can only be achieved by applying additional forces such as vacuum or pressure filtration or centrifugation, after which suitable dry stacking construction methods can be used.

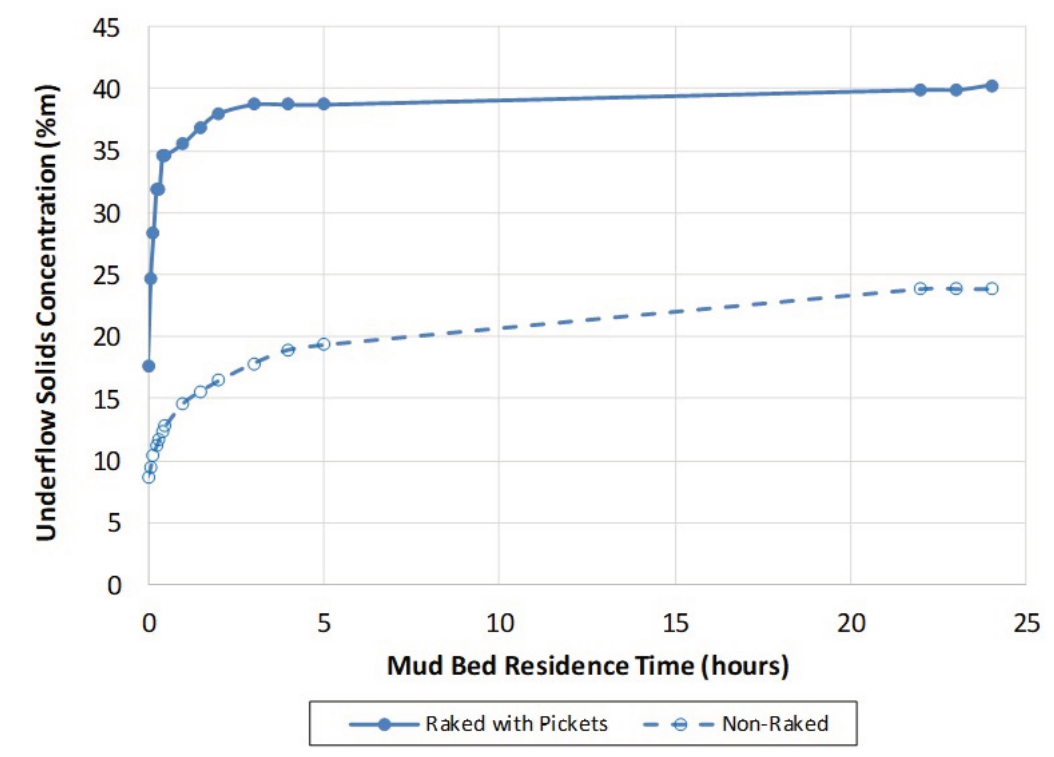

Figure 1 Comparison of mud bed consolidation in the presence and absence of pickets (kimberlite tailings)

P\&TT disposal is fundamentally a geotechnical discipline; however, it is ironic that many geotechnical practitioners know very little technical detail of the dewatering process equipment which determines the success, or not, of their projects. 
Williams et al. (2008) provided a list of 32 P\&TT disposal schemes that had been commissioned globally up until that time, and in which a variety of solid/liquid separation technologies had been included, such as various thickener types (raked and unraked) as well as filtration technology (belt press). Clearly, at the time, P\&TT schemes were not discriminated according to the dewatered properties of the tailings but rather according to the deposition site construction method. This discrepancy has led to possible confusion since although P\&TT schemes are designed assuming non-segregating tailings, not all of the dewatering technologies mentioned in the paper can generate non-segregating tailings. In the review by Williams et al. (2008), only eight schemes incorporating so-called deep cone thickeners (DCT) in their flowsheets can claim to be true P\&TT disposal schemes.

The origins and evolution of 'paste' thickener technology has been well documented (Schoenbrunn 2011; Schoenbrunn \& Bach 2015) and over time two thickener designs have become recognised as true paste thickeners; these being the deep cone thickener (DCT) and the high-density thickener (HDT) designs. The DCT type has dominated the P\&TT market, and more than 200 are currently installed in various backfill and surface tailings applications. Both units are picket raked; however, they have very different design features and applications (Table 1).

Table 1 Comparative table of deep cone and high-density paste thickeners

\begin{tabular}{|c|c|c|}
\hline Feature & Deep cone thickener & High-density thickener \\
\hline $\begin{array}{l}\text { Tank } \\
\text { diameter }\end{array}$ & Up to $45 \mathrm{~m}$ in diameter & $\begin{array}{l}\text { Generally larger than } 40 \mathrm{~m} \text { in } \\
\text { diameter }\end{array}$ \\
\hline $\begin{array}{l}\text { Tank cylinder } \\
\text { geometry }\end{array}$ & $\begin{array}{l}\text { High aspect ratio when }<20 \mathrm{~m} \text { diameter } \\
\text { Low aspect ratio when }>20 \mathrm{~mm} \text { diameter } \\
\text { Sidewall heights up to } 12 \mathrm{~m}\end{array}$ & $\begin{array}{l}\text { Low aspect ratio } \\
\text { Sidewall height up to } 7 \mathrm{~m}\end{array}$ \\
\hline Cone angle & $\begin{array}{l}\text { Steep cone } \\
30^{\circ} \text { from horizontal }\end{array}$ & $\begin{array}{l}\text { Shallow cone } \\
10-15^{\circ} \text { from horizontal }\end{array}$ \\
\hline $\begin{array}{l}\text { Rake drive } \\
\text { type }\end{array}$ & $\begin{array}{l}\text { Centre driven } \\
\text { Hydraulic or electric }\end{array}$ & $\begin{array}{l}\text { Centre or peripheral driven } \\
\text { Hydraulic or electric }\end{array}$ \\
\hline Rake lift & $\begin{array}{l}\text { None } \\
\text { Torque rating and mechanical strength } \\
\text { sufficient to protect rake }\end{array}$ & $\begin{array}{l}\text { Centre driven units may have rake } \\
\text { lift to protect gearbox and rake } \\
\text { structure }\end{array}$ \\
\hline $\begin{array}{l}\text { Torque } \\
\text { capability }\end{array}$ & Up to $14 \mathrm{MNm}$ for centre driven & $\begin{array}{l}\text { Up to } 14 \mathrm{MNm} \text { for centre driven } \\
>14 \mathrm{MNm} \text { for peripheral driven }\end{array}$ \\
\hline Rake type & $\begin{array}{l}\text { High strength, low-profile rake arms } \\
\text { Vertical pickets on rake always included }\end{array}$ & $\begin{array}{l}\text { High strength, low-profile rake arms } \\
\text { Vertical pickets on rake always } \\
\text { included }\end{array}$ \\
\hline $\begin{array}{l}\text { Underflow } \\
\text { discharge }\end{array}$ & $\begin{array}{l}\text { Because high yield stress slurries, elbows } \\
\text { and swept bends not recommended } \\
\text { Typically, discharge cylinder below cone with } \\
\text { horizontal off-take }\end{array}$ & $\begin{array}{l}\text { Because high yield stress slurries, } \\
\text { elbows and swept bends not } \\
\text { recommended } \\
\text { Typically, multiple off-takes below } \\
\text { the cone }\end{array}$ \\
\hline $\begin{array}{l}\text { Method of } \\
\text { construction }\end{array}$ & Normally steel structure built above-ground & $\begin{array}{l}\text { Normally concrete structure built } \\
\text { in-ground }\end{array}$ \\
\hline
\end{tabular}


It is proposed that P\&TT tailings disposal schemes should not be defined primarily on the method of TSF construction but rather based on the type of dewatering technology employed in the flow sheet (i.e. paste-type) thickeners either of the deep cone or high-density thickener design.

\section{The 'upstream' P\&TT design philosophy}

Within the tailings fraternity, there was an early acceptance of the 'upstream' P\&TT system design sequence in which the rheological requirement of the deposition site dictated the upstream transport and dewatering unit process design requirements (Boger et al. 2006). This design philosophy assumes that the dewatering process will, in all cases, dewater the tailings sufficiently to provide the ideal slurry rheological properties for the deposition site. Over time, this has proved not to be true, and, in most cases, the deposition design has had to be modified to accommodate density and rheological range achieved by the dewatering process. Recognition of this trend by geotechnical engineers has only recently been expressed, by Fitton (2017), who correctly states that:

\section{"...the dewatering method dictates the type of storage that must be designed for the tailings..."}

The 'upstream' design philosophy has inadvertently understated the importance of the metallurgical dewatering process in P\&TT schemes. Often it is the geotechnical engineer who specifies the dewatering equipment to be included into the flow sheet, rather than the mine owner's project metallurgist. Since the dewatering unit process forms part of the plant metallurgical circuit, it is incumbent that the mine owner's team should take greater ownership and hence obtain a greater understanding of the entire tailings disposal system. In this way, there will be greater recognition of P\&TT disposal at higher levels within the mining company.

It is proposed that the upstream design philosophy be replaced with a 'downstream' one in which the design of a P\&TT system is fundamentally based on the physical and chemical properties of the tailings. These determine the maximum density and rheological properties that can be achieved by various dewatering technologies which then direct the transport and deposition process designs (Figure 2).

- Point 1 refers to the tailings physical and chemical properties.

- Point 2 refers to the maximum tailings density and unsheared rheology achievable by a particular dewatering technology compared to the project design density requirements. This step sets the design parameters for the dewatering equipment and/or modification to the project design requirements.

- Point 3 refers to the maximum tailings density and sheared rheology determined from above for pump and pipeline design parameters.

- Point 4 refers to the delivered tailings density and sheared rheology for the depositional requirement design parameters.

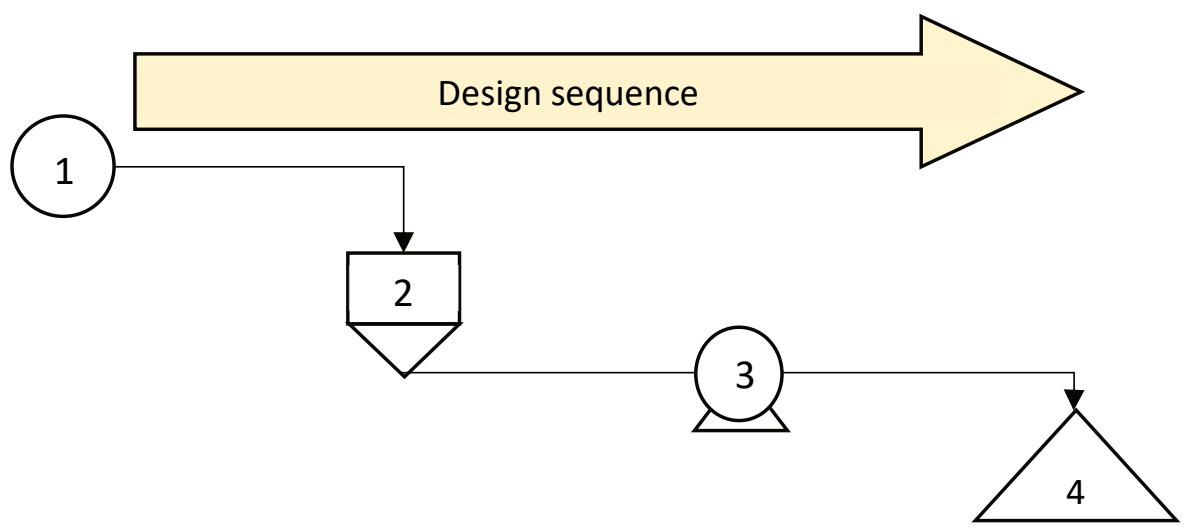

Figure 2 Downstream P\&TT design philosophy 


\section{$4 \quad$ Paste thickener developmental hurdles}

\subsection{Application in large tonnage operations}

As with all new metallurgical technologies, the transition from small to large tonnage applications often exposes technical challenges which were often unforeseen previously. Such mechanical challenges were experienced by both the DCT and HDT designs, particularly when the first large tonnage copper tailings P\&TT projects in South America were commissioned. Without a doubt, the problems experienced at these high-profile paste projects served to tarnish the stellar reputation of P\&TT disposal up to that point.

The chronological development of both DCT and HDT technology and their use in P\&TT disposal schemes in large tonnage copper mines is documented below. To provide context, the original DCT design was developed by Alcan and only became commercially available to the greater minerals industry in the mid-1990s after Eimco Process Equipment (now FLSmidth) obtained a licencing agreement from Alcan (Schoenbrunn \& Bach 2015). In contrast, the HDT has evolved from existing large diameter high-rate thickener designs supplied by the OEMs. The first design can be traced back to the $90 \mathrm{~m}$ diameter peripheral-rake driven 'superthickener' installed at the Alcoa Pinjarra plant in Australia (Cooling 2006).

The first large tonnage P\&TT disposal scheme outside of the alumina industry using the CTD method for TSF construction and incorporating DCTs in the flow sheet, was De Beers' Combined Treatment Plant in South Africa in 2002 (Paterson et al. 1999). At the time, DCT tank diameter was limited to $15 \mathrm{~m}$ and, therefore, $5 \times 15 \mathrm{~m}$ diameter units were required to treat $14,500 \mathrm{t} / \mathrm{d}$ of kimberlite tailings.

As confidence in the technology grew, tank diameter steadily increased to cater for greater tonnage loads, and by 2004, tank diameter had been increased up to $20 \mathrm{~m}$. However, it was the $2 \times 40 \mathrm{~m}$ diameter DCT installation in 2007 at the Wu Shan copper mine, China treating 35,000 t/d, which marked a milestone for the possibility of utilising P\&TT as a tailings disposal technology for the large tonnage copper producers in South America (Wu et al. 2011; Schoenbrunn 2011).

The first large tonnage $(95,000 \mathrm{t} / \mathrm{d})$ copper mine in South America to adopt P\&TT disposal was the then Minera Esperanza in Chile in 2010 (Gaete et al. 2014). Due to the limitation in DCT diameter, the mine decided to include $3 \times 60 \mathrm{~m}$ diameter HDTs into the flow sheet. Unfortunately, the underflow design requirement of $67 \% \mathrm{~m}$ was not met as the HDTs tended to experience high rake torque and were only able to thicken to approximately $62 \% \mathrm{~m}$. This challenge set in motion several design modifications that included replacing the existing rakes with low-profile picket rakes, which became standard in all future HDT designs. In addition, four years later, in 2014, the mine installed an additional $3 \times 45$ m diameter DCTs to treat a portion of the full plant tailings to increase the average mass concentration of the tailings to meet the P\&TT design requirement (Gaete et al. 2014). Currently, this is being achieved successfully.

The industry owes a large debt of gratitude to Antofagasta Minerals' Minera Esperanza (now Minera Centinela) for sharing their experiences, contributing significantly to the subsequent understanding and future design of P\&TT disposal schemes in other high tonnage copper operations.

In 2012, the first large tonnage copper tailings P\&TT scheme was implemented in Iran at NICICO's Sar Cheshme mine (MacNamara et al. 2011). This scheme was treating an equivalent tonnage as Minera Esperanza $(96,000 \mathrm{t} / \mathrm{d})$, but the flow sheet included several smaller diameter DCT units $(12 \times 24 \mathrm{~m}$ diameter). Even though there were initial commissioning problems, importantly, the requirement to produce a thickened tailings at the design requirement of 59 to $60 \% \mathrm{~m}$ at an unsheared yield stress of $150 \mathrm{~Pa}$ was met (Javadi et al. 2015). 
In 2013, the second very large copper tailings P\&TT scheme in South America was being commissioned at the Toromocho Mine in Peru. In this case, 124,000 t/d were dewatered using $4 \times 43 \mathrm{~m}$ diameter DCT units. Once again, high rake torque problems were reported leading to the design underflow density target of $69 \% \mathrm{~m}$ to $70 \% \mathrm{~m}$ not being achieved and the overall P\&TT design not being met (Johnson \& Vizcarra 2020).

The difficulty in achieving the project design underflow density targets experienced by the two South American P\&TT schemes (using different thickening technology) was investigated at a panel discussion held at Paste 2016 in Santiago, Chile during 2016 (Barera \& Engels 2018). The operational challenges experienced at the HDTs at Centinela and the DCTs at Toromocho were compared to the equally high tonnage Iranian Sar Cheshme operation, which did not appear to suffer from these difficulties. The discussion concluded that this difference was due to the lower discharge target at Sar Cheshme $(60 \% \mathrm{~m})$ compared to the higher targets of Centinela $(67 \% \mathrm{~m})$ and Toromocho $(70 \% \mathrm{~m})$.

The unsheared yield stress curves from two datasets representing five paste thickened copper tailings projects in South America and four paste thickened copper tailings projects in Iran collected from case study data presented at previous paste and thickened tailings seminars and the author's database are compared. The Iranian copper tailings tend to show higher unsheared yield stresses at equivalent mass concentrations than the South American copper tailings. Therefore, the Sar Cheshme tailings at the design underflow solids concentration of $60 \% \mathrm{~m}$ would have a similar unsheared yield stress (approximately $150 \mathrm{~Pa}$ ) as the Centinela tailings at $67 \% \mathrm{~m}$. The Toromocho tailings at $70 \% \mathrm{~m}$ would be expected to have an even higher unsheared yield stress close to $200 \mathrm{~Pa}$ (Figure 3).

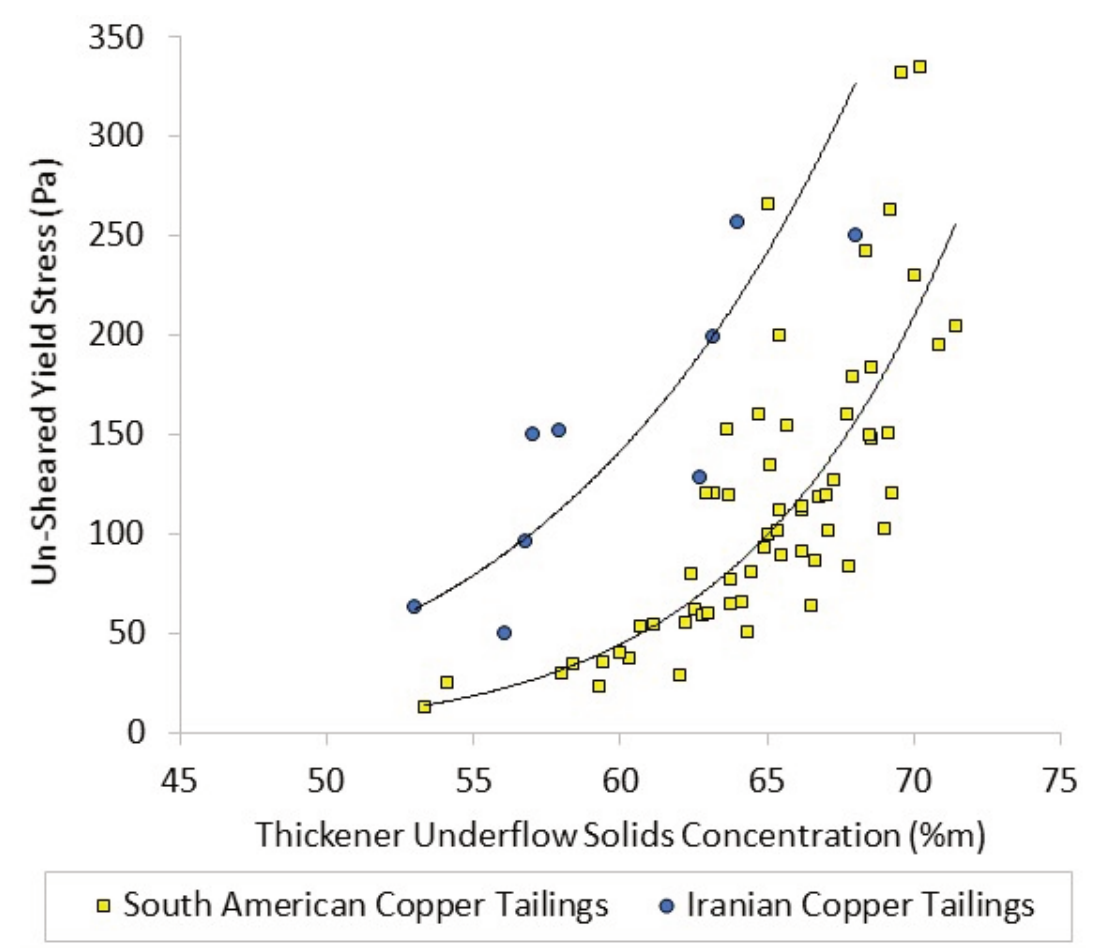

Figure 3 Relationship between unsheared yield stress and solids concentration in Iranian and South American copper tailings

This evidence points to the possibility that the installed rake gearbox torque capacity at the Centinela and Toromocho thickeners may not have been sufficiently high enough to cope with the high unsheared yield stress operating requirement. 


\subsection{Determining paste thickener rake torque}

Sizing of the rake gearbox in terms of torque requirement is probably the riskiest aspect of paste thickener design since under-sizing may result in either the rake stalling and subsequent digging out of the thickener, or, at the very best, operating the thickener at a lower than desired underflow density.

Historically the maximum operating torque (MOT) or duty rated torque for conventional or high-rate thickeners was calculated in Imperial units using the following equation:

$$
\text { Maximum operating torque }(\mathrm{ft}-\mathrm{lbs})=\mathrm{K} * \mathrm{D}^{2}
$$

where:

$$
\begin{aligned}
& \mathrm{K}=\text { dimensionless factor historically derived from empirical observation. } \\
& \mathrm{D}=\text { thickener diameter }(\mathrm{ft}) .
\end{aligned}
$$

To convert the answer into SI units of torque $(\mathrm{Nm})$, a conversion factor of 14.6 was applied, or the equation could be re-written as:

$$
\text { Maximum operating torque }(\mathrm{Nm})=\mathrm{K} * \mathrm{D}^{2} * 14.6
$$

where:

$$
\mathrm{D}=\text { thickener diameter }(\mathrm{m}) \text {. }
$$

Table 2 provides a selection of dimensionless K-factors derived from empirical observation used to calculate the MOT for conventional and high-rate thickeners in different applications (Schoenbrunn \& Laros 2009; Schoenbrunn et al. 2019).

\section{Table 2 Thickener duty and K-factors}

\begin{tabular}{ll}
\hline Thickener duty & Standard K-factor \\
\hline Light & $1-4$ \\
Standard & $5-9$ \\
Heavy (copper tailings) & $20-40$ \\
Extra heavy & $40-60$ \\
\hline
\end{tabular}

After installation, the vendors would recommend that the rake drive be operated at a normal operating torque (NOT), a fraction of the MOT (typically in the order of 20 to 30\%) to provide a margin of safety for the gearbox mechanical components. Since conventional and high-rate thickeners generally operate under low-density conditions, there are almost no unsheared yield stresses to overcome, and the rake can operate even at the lower torque setting.

In paste thickeners, however, the rakes need to contend with high-density slurries with significant unsheared yield stresses, and hence the K-factors applied to sizing the torque requirements of paste thickeners are orders of magnitude greater than the standard K-factors used previously (Schoenbrunn et al. 2019). It is also commonly accepted that the unsheared yield stress of a tailings can be used as a relatively good proxy for the K-factor. Schoenbrunn et al. (2019) provided data relating K-factor to underflow density for thickeners in copper tailings circuits over $25,000 \mathrm{t} / \mathrm{d}$ (Caro et al. 2016). This relationship is overlayed with the unsheared yield stress data for South American copper tailings projects in Figure 3, and it shows a relatively good correlation between $\mathrm{K}$-factor and unsheared yield stress (Figure 4). 


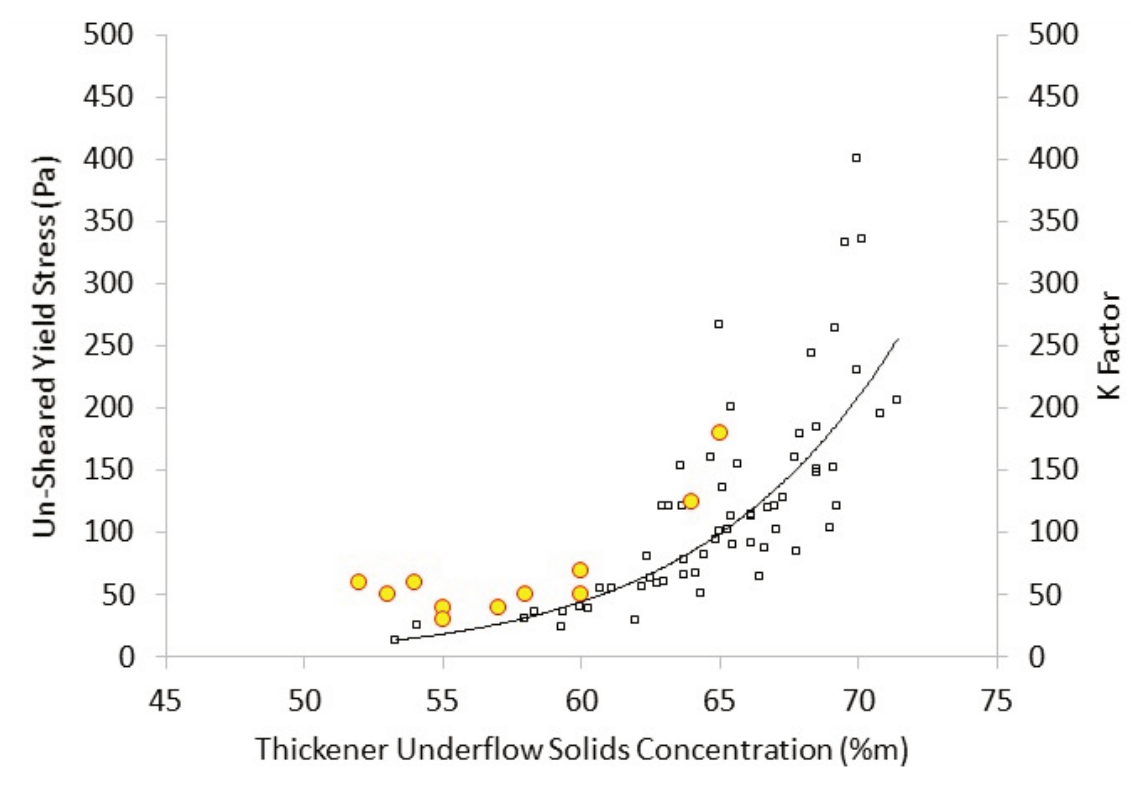

- South American Data ○ K-factor Data for Large Copper Projects (Schoenbrunn)

Figure 4 Correlation of K-factors used in copper tailings thickening projects and the unsheared yield stress of various South American copper tailings

Unlike conventional and high-rate thickeners, the MOT for paste thickeners which has been calculated to allow the rake to operate at the project design underflow density and unsheared yield stress cannot operate at a lower torque for gear component life considerations. This would be a fatal flaw in the P\&TT disposal system. Seven high-tonnage copper tailings P\&TT case studies in Iran and South America were compared to determine if the K-factors used to calculate the installed MOT was in excess, equal to, or less than the unsheared yield stress of the underflow at the project design density target (Figure 5). The P\&TT schemes used in the case study are listed in Table 3.

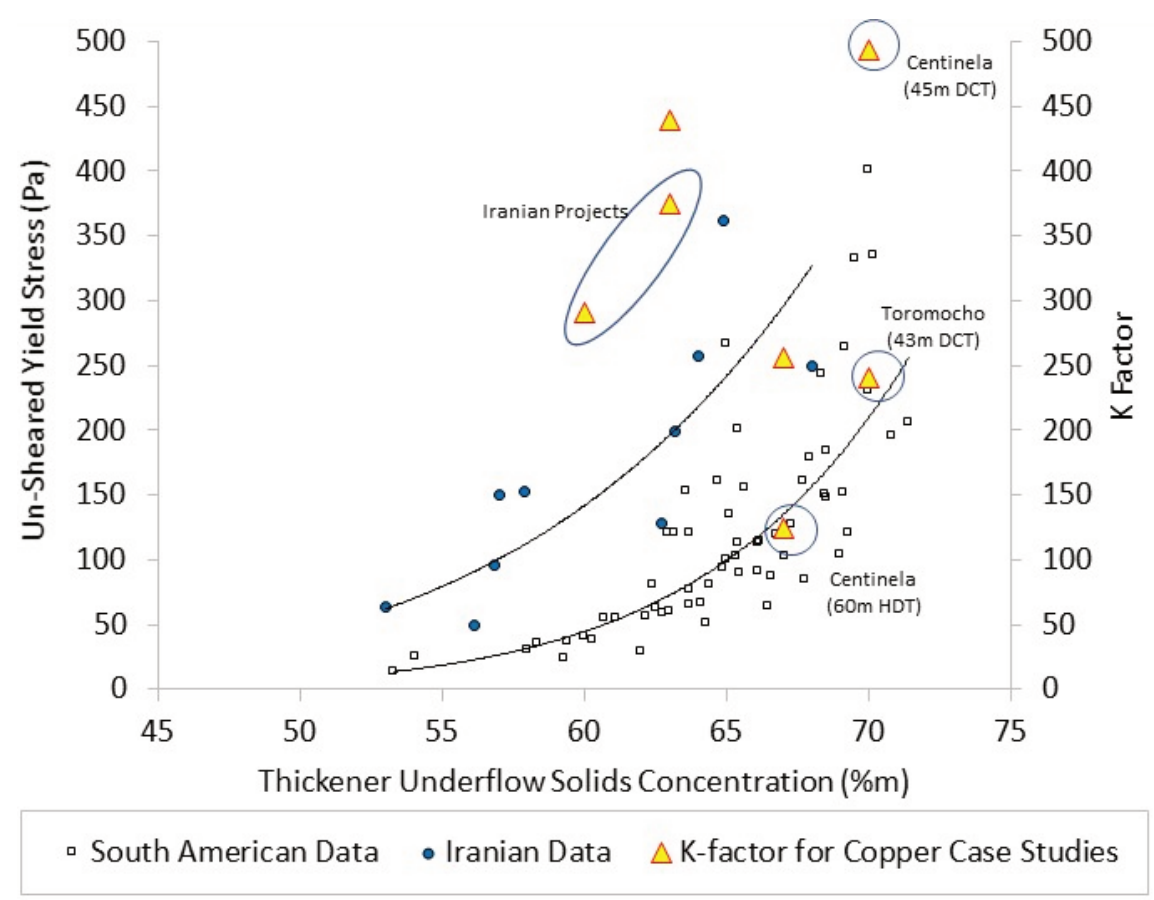

Figure 5 Correlation of P\&TT case study K-factors and the unsheared yield stress of various South American and Iranian copper tailings 
Table 3 Copper tailings P\&TT case study

\begin{tabular}{|c|c|c|c|c|c|c|c|c|}
\hline $\begin{array}{l}\text { Project } \\
\text { name }\end{array}$ & Thickener & $\begin{array}{l}\text { Diameter } \\
\text { (m) }\end{array}$ & $\begin{array}{l}\text { Design } \\
\text { density } \\
(\% \mathrm{~m})\end{array}$ & $\begin{array}{l}\text { Estimated } \\
\text { unsheared } \\
\text { yield stress } \\
(\mathrm{Pa})\end{array}$ & $\begin{array}{l}\text { Installed } \\
\text { MOT } \\
\text { (MNm) }\end{array}$ & $\begin{array}{l}\text { Calculated } \\
\text { K-factor }\end{array}$ & $\begin{array}{l}\text { Ratio } \\
\text { K:yield } \\
\text { stress }\end{array}$ & Reference \\
\hline Miduk & DCT & 16 & 63 & 200 & 1.4 & 375 & 1.9 & $\begin{array}{l}\text { Williams et al. } \\
\text { (2006) }\end{array}$ \\
\hline Collahuasi & HDT & 22 & 63 & 120 & 3.1 & 439 & 3.7 & $\begin{array}{l}\text { Loan et al. } \\
\text { (2011) }\end{array}$ \\
\hline Esperanza & HDT & 60 & 67 & 150 & 6.5 & 124 & 0.8 & $\begin{array}{l}\text { F Bello, pers. } \\
\text { comm., } 2021\end{array}$ \\
\hline $\begin{array}{l}\text { Telabre } \\
\text { Project }\end{array}$ & HDT & 60 & 67 & 150 & 13.4 & 256 & 1.7 & $\begin{array}{l}\text { F Bello, pers. } \\
\text { comm., } 2021\end{array}$ \\
\hline Centinela & DCT & 45 & 70 & 250 & 14.6 & 494 & 2.0 & $\begin{array}{l}\text { Gaete et al. } \\
\text { (2014) }\end{array}$ \\
\hline $\begin{array}{l}\text { Sar } \\
\text { Cheshmeh }\end{array}$ & DCT & 24 & 60 & 150 & 2.4 & 291 & 1.9 & $\begin{array}{l}\text { Javadi et al. } \\
\text { (2015); } \\
\text { L MacNamara, } \\
\text { pers comm., } \\
2021\end{array}$ \\
\hline Toromocho & DCT & 43 & 70 & 250 & 6.5 & 241 & 1.0 & $\begin{array}{l}\text { Johnson \& } \\
\text { Vizcarra } \\
\text { (2020); } \\
\text { F Bello, pers. } \\
\text { comm., } 2021\end{array}$ \\
\hline
\end{tabular}

The results indicate that the large diameter Centinela and Toromocho thickeners were equipped with rake drives sized to operate precisely at the design underflow density, and that there was no torque margin of safety. If the thickener torque operating set-points were set at any level lower than $100 \%$, the rakes would not have sufficient torque to operate at the design density but would have had to operate at a lower underflow density setting.

In contrast, the DCTs at the Iranian P\&TT schemes appear to be equipped with rake drives with MOT capabilities in excess of the torque requirement for the design project underflow density targets. However, it should be remembered that the Iranian DCT diameters are far smaller than those at both Centinela and Toromocho, and that torque increases with the tank diameter to the power of two.

More recently, thickener OEMs have come to recognise this short-coming in large centre driven DCTs and HDTs, and so are introducing 'safety factors' to be applied to the K-factor in the MOT calculation to take into account the margin of safety required for gear component life and upset conditions at the thickeners.

It is proposed that the MOT determination for centrally driven DCT and HDT, be calculated as follows starting with the NOT:

$$
\text { Normal operating torque }(\mathrm{Nm})=\mathrm{V} * \mathrm{D}^{2} * 14.6
$$

where:

$$
\begin{aligned}
\mathrm{V}= & \text { dimensionless factor approximated by the unsheared yield stress at the design underflow } \\
& \text { density. } \\
\mathrm{D}= & \text { thickener diameter }(\mathrm{m}) .
\end{aligned}
$$




$$
\text { Maximum operating torque }(\mathrm{Nm})=\mathrm{NOT} * \mathrm{SF}
$$

where:

$$
\mathrm{SF} \quad=\text { safety factor (typically a factor up to two) }
$$

As the need to treat greater tailings tonnages increases, larger diameter thickeners will be required. FLSmidth has recently introduced a 'super duty' drive which, at $16.4 \mathrm{MNm}$, is the largest centre drive gearbox on the market (FLSmidth 2021). However, the torque requirement for centrally driven rake systems will become mechanically limiting, and peripherally driven rake systems will need to be considered. The major advantage of these systems is that torque availability is virtually open-ended and the thickener can continuously operate at $100 \%$ of the installed MOT.

\section{Conclusion}

The need for a metallurgical change within the mining industry to eliminate wet tailings dams is urgent and will be imposed by external pressure from investors and society in general. However, under this pressure, the knee-jerk reaction from the industry has been to focus entirely on dry stacking disposal, which employs dewatering technology, hither to largely untried, at large tonnage scale.

Paste, and thickened tailings disposal has, in contrast, over the past two decades been implemented very successfully at small to medium scale and, although the learning curve has been difficult, it has been applied at very large scale. It is therefore, imperative that the mining and geotechnical fraternity do not ignore the benefits of this now mature technology going forward.

This paper recognises and attempts to bridge the knowledge gaps that exist within the tailings fraternity (consultants, mine personnel and OEMs) regarding P\&TT system design and definition. It also provides an explanation for the failure of early large tonnage projects in achieving their design targets and how these can be overcome in future designs.

\section{Acknowledgement}

The author thanks the many contributors who helped provide data for this paper to be published.

\section{References}

Barrera, S \& Engels, J 2018, 'High-density thickening for large production rate: main challenges', in RJ Jewell \& AB Fourie (eds), Paste 2018: Proceedings of the 21st International Seminar on Paste and Thickened Tailings, Australian Centre for Geomechanics, Perth, pp. 35-42.

Boger, D, Scales, P \& Sofra, F 2006, 'Chapter 3: Rheological concepts', in RJ Jewell \& AB Fourie (eds), Paste and Thickened Tailings A Guide, 2nd edn, Australian Centre for Geomechanics, Perth, pp. 25-38.

Caro, G, Schoenbrunn, F, Becerra, M \& Kujawa, C 2016, 'Challenges in implementation of highly thickened tailings technology in large production rates', Paste 2019: Proceedings of the 19th International Seminar on Paste and Thickened Tailings, Santiago, https://gecamin.com/paste2016/images/panel/16PST\%20Discussion_panel_transcription\%2017.01.25.pdf

Cooling, D 2006, 'Chapter 12: Case studies', in RJ Jewell \& AB Fourie (eds), Paste and Thickened Tailings - A Guide, 2nd edn, Australian Centre for Geomechanics, Perth, pp. 203-205.

Fitton, TG 2017, 'Avoiding large tailings dams without going underground - Robinsky's thickened tailings concept', in RJ Jewell \& AB Fourie (eds), Paste 2017: Proceedings of the 20th International Seminar on Paste and Thickened Tailings, University of Science and Technology Beijing, Beijing, pp. 243-249.

FLSmidth 2020, Thickener Evolution: A Testament to Customer Satisfaction, viewed 20 April 2021, https://www.flsmidth.com/en$\mathrm{gb} /$ customer-stories/thickener-evolution-a-testament-to-customer-commitment

Franks, DM, Stringe, M, Torres-Cruz, M, Baker, E, Valenta, R, Thygesen, K, Matthews, A, Howchin, J \& Barrie, S 2021, 'Tailings facility disclosures reveal stability risks', Nature Portfolio, Scientific Reports, vol. 11, no. 5353.

Gaete, S, Bello, F, Engels, J \& McPhail, GI 2014, 'Thickening and deposition trials: laboratory through to industrial scale - Minera Esperanza', in RJ Jewell \& AB Fourie (eds), Paste 2014: Proceedings of the 17th International Seminar on Paste and Thickened Tailings, Infomine Inc., Vancouver, pp. 381-392.

Javadi, S, Pirouz, B, Williams, MPA, Zarabadi, A \& Sief, HR 2015, 'Sarcheshmeh copper mine paste plant design, start up and early operation overview', in RJ Jewell \& AB Fourie (eds), Paste 2015: Proceedings of the 18th International Seminar on Paste and Thickened Tailings, Australian Centre for Geomechanics, Perth, pp. 107-115. 
Johnson, J \& Vizcarra, J 2020, 'Modernization of Chinalco Toromocho copper tailings thickeners', Paste 2020: Proceedings of the 23rd International Conference on Paste, Thickened and Filtered Tailings, Gecamin Publications, Santiago, https://doi.org/10.36487/ACG_repo/2052_35

Loan, C, Villanueva, ML \& Saldia, N 2011, 'Collahuasi paste thickener - pilot and full scale results', in RJ Jewell \& AB Fourie (eds), Paste 2011: Proceedings of the 14th International Seminar on Paste and Thickened Tailings, Australian Centre for Geomechanics, Perth, pp. 101-110.

MacNamara, L, Khoshniaz, N \& Hashemi, S 2011, 'The Sarcheshmeh thickened tailings disposal project', in RJ Jewell \& AB Fourie (eds), Paste 2011: Proceedings of the 14th International Seminar on Paste and Thickened Tailings, Australian Centre for Geomechanics, Perth, pp. 237-243.

Paterson, AJC, Johnson, G \& Vietti, AJ 1999, 'Case study: pumping high density kimberlite tailings', Proceedings of the 14th International Conference on Slurry Handling and Pipeline Transport: Hydrotransport 14, Professional Engineering Publishing, Bury St Edmunds, pp. 567-586.

Schoenbrunn, F 2011, 'Dewatering to high density - an industrial review', in RJ Jewell \& AB Fourie (eds), Paste 2011: Proceedings of the 14th International Seminar on Paste and Thickened Tailings, Australian Centre for Geomechanics, Perth, pp. 19-23.

Schoenbrunn, F \& Bach, M 2015, 'The development of paste thickening technology and its application in the minerals industry - an industrial review', Berg-und Hüttenmännische Mantashefte, vol. 106, no. 6, pp. 257-263.

Schoenbrunn, F \& Laros, T 2009, 'Chapter X: design features and types of sedimentation equipment', in AL Mular, DN Halbe \& DJ Barratt (eds), Mineral Processing Plant Design, Practice and Control, vol. 1, Society for Mining, Metallurgy \& Exploration, New York.

Schoenbrunn, F, Laros, T, Hendriksson, B \& Arbuthnot, I 2019, 'Chapter 8.1: sedimentation equipment', in RC Dunne, S Komar Kawatra \& Young, CA (eds), SME Mineral Processing \& Extractive Metallurgy Handbook, Society for Mining, Metallurgy \& Exploration, New York.

Williams, MPA, Murphy, SD, MacNamara, L \& Koshniaz, N 2006, 'The Miduk copper project: down-valley discharge of paste and thickened tailings, design and early operation experience', in RJ Jewell \& AB Fourie (eds), Paste 2006: Proceedings of the 9th International Seminar on Paste and Thickened Tailings, Australian Centre for Geomechanics, Perth, pp. 117-130.

Williams, MPA, Seddon, KD \& Fitton, TG 2008, 'Surface disposal of paste and thickened tailings - a brief history and current confronting issues', in RJ Jewell \& AB Fourie (eds), Paste 2008: Proceedings of the 11th International Seminar on Paste and Thickened Tailings, Australian Centre for Geomechanics, Perth, pp. 143-164.

Wu, A-X, Jiao, H-Z, Wang, H-J, Jang, S-K, Li, L, Yan, Q-W \& Liu, H-J 2011, 'Status and development trends of paste disposal technology with ultra-fine unclassified tailings in China', in RJ Jewell \& AB Fourie (eds), Paste 2011: Proceedings of the 14th International Seminar on Paste and Thickened Tailings, Australian Centre for Geomechanics, Perth, pp. 477-489. 
